\title{
Interpretive structural modeling of critical factors for buyer-supplier partnerships in supply
} chain management

\author{
Nejah Ben Mabrouk $\mathbf{a}^{*}$
}

${ }^{a}$ Department of Management Information Systems and Production Management, College of Business and Economics (CBE) - Qassim University, P.O.Box: 6640, Buridah 51452, Saudi Arabia

\begin{tabular}{l}
\hline C H R O N I C L E \\
\hline Article history: \\
Received November 28, 2019 \\
Received in revised format \\
January 30, 2020 \\
Accepted February 112020 \\
Available online \\
February 112020 \\
\hline Keywords: \\
Supply chain management \\
Buyer \\
Supplier \\
Relationships \\
Interpretive Structural \\
Modeling
\end{tabular}

\begin{abstract}
A B S T R A C T
In today's complex and competitive environment, supply function becomes more a strategic differentiator and a core competency. This function is strongly related to relationship between buyer and supplier. In addition, buyer supplier relationships (BSR) have undertaken considerable changes during the last decade. Although previous empirical research has found the importance of identifying factors that influence BSR, the present paper analyses the factors influencing the successful relationship between buyer and seller. Based on the Interpretive Structural Modeling (ISM), the complex interrelationships between the established factors are inspected. Classification of factors has been carried out based on dependence and driving power by using MICMAC analysis. The present study highlights "Innovation and technology" and "Information exchange" as the most significant factors with high influential power for the BSR. This study aims to aid the decision makers (buyer or supplier) in evolving effective business strategies.
\end{abstract}

C 2020 by the authors; license Growing Science, Canada.

\section{Introduction}

The main effort in supply chain management (SCM) is to develop productive partnerships, integrate buyer-seller activities with an interest in adding value, optimize productivity through efficiencies and achieve customer satisfaction (Hüttinger et al., 2012; Yu et al., 2013; Carmen \& Cubillo, 2019). Relationship management is crucial because supply chains (SC) are typically complex with different operations normally spread across multiple functions and entities and sometimes over long horizons of time. Therefore, a management system needs to be overlaid, which can include a clear description of procedures, roles and systems consistent with the overall objective of a whole SC. It is crucial that the partners in the SC understand the factors having impact on their relationships. The identification of the influence of these factors should be used to focus the efforts of any company on the most important areas, which improves the sustainable competitive advantage resulting from that relationship (Vargas et al., 2018). Customer and supplier relationships are discussed from the viewpoint of small and medium-sized enterprises (Morrissey \& Pittaway, 2006). The analysis found that buying was regarded as an important consideration of management and that the existing paradigm centered on the strategies

\footnotetext{
* Corresponding author

E-mail address: mabrouknejah@gmail.com (N. Ben Mabrouk)

(C) 2020 by the authors; licensee Growing Science.

doi: $10.5267 /$ j.uscm.2020.2.002
} 
of larger firms was focused on collective principles. The importance of BSR has been extensively discussed in the industrial marketing literature. BSR were known as central strategic boundary decisions achieving business performance (Luo et al., 2015; Zhang et al., 2019). Many studies have tried developing models to capture the importance of BSR (Schönberger, 2011; Luo et al., 2015). Developing and maintaining sustainable relationship in business-to business exchanges is very important for any buyer/supplier, for making sustainable competitive advantage (Kumar \& Rahman, 2016). According to Cannon and Homburg (2001), in order to create value, Costs in commercial trade must be reduced. The developed model clarifies the impact of both the behaviors and the management of suppliers on acquisition, direct product and operations costs of customer firms.

There are a number of factors that need to be considered while studying relationship between buyer and supplier. According to Wu et al. (2016), trust and commitment are considered as critical factors for BSR sustainability, and these two factors are strongly related to each other (Nyaga et al., 2010). Successful relationship between supply chain partners needs commitment, and trust is a critical component to sustain such commitment (Kingshott, 2006). In addition, satisfaction and performance relationship are influenced by trust and commitment. Also, they ease the creation of productive collaborations and relationships (Han et al., 2014). Buyer-supplier relationship becomes more rapidly and robust over the exchange of information at both the ends. Information exchange leads up to assure higher supplier relationships quality (Caglio \& Ditillo, 2012).

This paper is structured as follows: Firstly, the need of this study is presented. Then, a brief literature review and factors identification is discussed. Next, a section detailing the research methodology based on ISM is presented. This approach is used to assess the importance of each factor when BSR is being implemented. Then, the obtained results are illustrated with the investigation of their implications. Finally, concluding remarks and limitations of this research are presented.

\section{The Need of the study}

The relationships between buyer and supplier influenced by several factors, in turn, are related to each other. Nevertheless, there are few researches that examine analytically the interactive relations between the factors affecting the buyer supplier relationships. The study conducted by Amy (2009) has classified the challenges into causal and effect factors. He used fuzzy analytic hierarchy process (AHP) model improved by an in-depth analysis in order to mitigate their global effect on buyer-supplier relationships. In this work, we applied ISM approach to study the direct and the indirect relationships with the logical inferences about the reason of existence of a relationship between any two factors that influences the buyer-supplier relationships. ISM offers the following advantages:

- Develops a hierarchical framework to examine the inter-relationships between the selected factors that affect buyer-supplier relationships;

- Considers and assesses both the direct and the indirect interactions between factors. Furthermore, it offers extensive opportunities to review the findings.

The ISM method is used to make a hierarchical structure between factors, and the MICMAC software technique is applied in order to examine, for each factor, the associated driving-power and dependencepower. This analysis aims to recognize the factors that are performed as the driving factors to the implementation of successful relationships between buyer and supplier, and the factors that are performed as the dependent ones.

\section{Literature review of critical factors influencing buyer-supplier relationships}

To identify Critical factors influencing buyer-supplier relationships, a systematic approach for identifying and updating relevant literature was implemented in this research. Science network site has been selected. Keywords of "factors", buyer", "supplier" "relationships" "supply chain" or other terms associated with buyer-supplier relationships, such as "Supply chain Partnership", "priority of 
importance", "performance ranking" and so on, to search for the database. Such articles were checked where they defined a set of factors.

Commitment: Commitment is characterized as a desire to create a stable relationship, a willingness to create short-term sacrifices in order to preserve the relationship, a trust in the relationship's stability and investments in the relationship (Chae et al., 2017). Commitment to relationships is defined as an exchange partner who finds a lasting relationship with another to be so important that it needs maximum effort to maintain it. (Morgan \& Hunt, 1994). According to Chiu et al. (2015), commitment represents the ongoing need for a person to maintain an organizational relationship.

Trust: Trust is seen as a crucial element in the process of building relationships. If the degree of trust among partners is considered high, there is also a greater willingness to engage in such a relationship, ultimately it leads to higher rates of satisfaction. Alternatively, the literature focused on creating interorganization trust (Akgün et al., 2005). Trust was seen as a characteristic or aspect of the relationship's quality and a determinant of the success of relationships (Ranaweera \& Prabhu, 2003; Doney \& Cannon, 1997).

Satisfaction: Satisfaction is seen as the level to which the management side of the relationship gives potential value and in which each party to the relationship should be satisfied with the other's results (Powers \& Reagan, 2007). According to Clampit et al. (2015), this is part of the relationship experience of the customer supplier where the parties agree to continue the relationship. It is stated that the level of satisfaction within the supply chain decreased in line with the desired response results between partners, resulting in increased conflict (Huang et al., 2003).

Innovation and technology: Supply chain technologies are one of the key elements that connect supply chain organizations into a cohesive and organized network (Wu et al., 2016). Technology is considered to be the degree partners who value the technology that the partnership contributes, if both parties benefit (Revilla \& Villena, 2012). This leads to greater interaction with the relationship and interdepends on the tools and benefits of the partnership (Roy et al., 2004).

Information exchange: Suppliers have more insight into specific areas or a long-standing industry experience that they can share with a client. There is much progress in cooperation between buyers and suppliers (Islam, 2019). According to Hwang et al. (2019), the integration of suppliers in new product development requires efficient exchange of information and absorption between purchaser and supplier. With the growing role of the internet in linking supply chain parties, Wu et al. (2016) address the effect on firm product innovation of internet-based collaboration. Clear contact and timely sharing of information serve as useful safeguards to avoid potential threats, disputes and confusion (Liu et al., 2017).

Quality: In terms of quality, there are several factors that can contribute to the success of a BSR. Supplier commodity strength benefits customers by secure, easy to use and easy to maintain operations. Quality is related to the essence of the organizations involved, their individuals and the severity of the situation (Parsons, 2002). According to Schönberger (2011), High-quality buyer-supplier relationships can make service transactions more effective by offering a stable form of hybrid governance between the customer and the hierarchy.

Supply chain Capabilities: Production capabilities is defined as the capacity of the supplier to fulfill the SC partner's demand with the required quantities, while being flexible enough to respond to changes in volumes and varieties (Kingshott, 2006). Production capabilities is considered as the capability of timeliness of delivery and the degree to which an entity can address changes in customer demand (Mohanty and Gahan, 2002; Arráiz et al., 2013). SC capability refers to the process of coordination and cooperation between suppliers, producers and consumers in order to achieve common objectives (Paulraj and Chen, 2007).

Safeguards: Contacts with potential suppliers can be seen as protection or back-up, but the dependence of the customer on the supplier can also be minimized. The safeguards include the techniques used to 
insure that the transactions between firms occur as intended (Christy \& Grout, 1994). In the context of risky buyer-supplier partnerships, Mesquita and Brush (2008) clarify the protection and collaboration effects of interfirm governance structures. Several researchers emphasized the importance of governance in BSR. The drive of these mechanisms is considered as a safeguard against disputes to create an atmosphere of effective cooperation and trust in the relationship among partners in the SC (Yen et al., 2011; Liu et al., 2017).

Cost reduction: One way of working together to achieve price reductions is to develop relationships between customer and supplier. If a partnership offers a forum for low purchase prices, the cost reduction can be achieved (Krause et al., 2007). The cost reduction can be defined then as the minimum amount the suppliers accept to sell to the firm (Luo et al., 2015). Cost reduction is seen as a competitive advantage with others, and businesses have also been slowly seeking to create a competitive advantage by creating a durable relationship with contractors (Cox, 2004).

Flexibility: Flexibility is defined as the product range, enhancing business ' aptitude to react rapidly and delivering good performance across a wide variety of products. It perceived the manufacturer's ability to offer flexible service in relation to quantity, type of product and preparation time, etc. De Toni and Tonchia (2005) defined flexibility as a capability of adaptation and change. Flexibility is characterized by the business area (product development, sourcing, distribution, logistics, etc.) and the roles and characteristics of the supply chain are specified for each business area. (Moon et al., 2012).

Cooperation: Cooperation between customer and supplier is a collaborative effort to meet common goals and expectations that cannot be accomplished independently (Brito et al., 2014). Cooperation between SC parties is important in terms of their ability to operate in harmony to achieve common goals such as business performance (Zhang et al., 2019). Organizations must collaborate with their suppliers and customers in order to develop sustainable competitive advantages (Wagner et al., 1998).

Corporate reputation: Corporate reputation is described as the perceptual representation of the organization's overall appeal to all its main partners in comparison with other leading competitors (Fombrun \& Pan, 2006). According to Suh and Houston (2010), the relationship partner's reputation impacts relationship attitudes and intentions. Some research, however, highlights the growing role that corporate reputation plays, especially in business to business markets (Money et al., 2017). It is considered a factor that strongly influences the decision to select the supplier (Manello and Calabrese, 2019) and the duration of partner relationship in supply chain (Matuleviciene \& Stravinskiene, 2015).

\section{Table 1}

CSFs affecting buyer-supplier relationships

\begin{tabular}{|c|c|c|}
\hline No. & Factors & Supporting literature \\
\hline 1 & Commitment & $\begin{array}{l}\text { Morgan and Hunt (1994), (Chae et al., 2017), Nyaga et al. (2010), Chiu et al. } \\
\text { (2015), (Kingshott, 2006) }\end{array}$ \\
\hline 2 & Trust & $\begin{array}{l}\text { Doney and Cannon(1997), Ranaweera and Prabhu (2003), (Akgün et al. } \\
\text { 2005), Wu et al. (2016), Nyaga et al. (2010) }\end{array}$ \\
\hline 3 & Satisfaction & $\begin{array}{l}\text { Huang et al. (2003), Powers and Reagan (2007), Clampit et al. (2015), } \\
\text { (Kingshott, 2006) }\end{array}$ \\
\hline 4 & Innovation and technology & Roy et al. (2004), Revilla and Villena (2012), Wu et al. (2016) \\
\hline 5 & Information exchange & $\begin{array}{l}\text { Caglio et al. (2012), Wu et al. (2016), Liu et al. (2017), Islam (2019) Hwang } \\
\text { et al. (2019) }\end{array}$ \\
\hline 6 & Quality & Parsons (2002), Schönberger (2011), Caglio and Ditillo (2012) \\
\hline 7 & Supply chain capabilities & $\begin{array}{l}\text { Mohanty and Gahan (2002), Arráiz et al. (2013), (Kingshott, 2006), (Paulraj } \\
\text { and Chen, 2007). }\end{array}$ \\
\hline 8 & Safeguards & Christy and Grout (1994), Mesquita and Brush (2008) Yen et al. (2011) \\
\hline 9 & Cost reduction & Cox (2004), Krause et al. (2007) Luo et al. (2015) \\
\hline 10 & Flexibility & De Toni and Tonchia (2005), Moon et al. (2012), (Han et al., 2014) \\
\hline 11 & Cooperation & Wagner et al. (1998), Brito et al. (2014), Zhang et al. (2019) \\
\hline 12 & Corporate reputation & $\begin{array}{l}\text { Matuleviciene and Stravinskiene (2015), Fombrun and Pan (2006), Suh and } \\
\text { Houston (2010), Money et al. (2017), Manello and Calabrese (2019) }\end{array}$ \\
\hline
\end{tabular}




\section{Research methodology}

\subsection{ISM approach}

ISM methodology was first developed to solve complex problems. ISM is an empirical method by which individuals or groups may establish a framework of all existing relationships between the various components of a complex structure (Warfield, 1974). Sage (1977) defines this approach as an interactive learning method that incorporates in a systemic, structured model a set of diverse yet directly linked elements. ISM is considered an operative method for defining the relationships between different elements of a composite system (Abuzeinab et al., 2017; Luthra et al., 2011). It has been used successfully in various real-life applications: to assess barrier power analysis of driving and dependency in the implementation of green SCM (Mathiyazhagan et al., 2013; Majumdar \& Sinha, 2019), to examining interactions of reverse logistics barriers (Govindan et al., 2012), to evolving the mutual relationship among sustainable supply chain determinants (Bhaskar et al., 2019).

\subsection{Data collection process}

Evaluation using ISM generally involves an interview with experts with diverse field knowledge and experience. This research was mainly targeted towards supply chain professionals in decision making positions in various Tunisian firms and the target group was the middle and top-level professionals. In this analysis, a sample size of 95 experts was considered. These experts include purchasing Managers and policy makers having relevant experience in the business area.

They were initially clarified by a preliminary set of challenges found in the previous study. A questionnaire was then distributed to each expert and opinions were sought on the contextual relationships between two variables (VAOX) together with their interpretations. The preferences are further aggregated for the relationships between two variables dependent on the highest frequencies. The research has just started as we prepare this paper, 72 complete responses have been obtained and used for analysis. Table 2 displays the demographic profile of the survey respondents.

\subsection{ISM Model development}

We use the following steps to establish the hierarchical relationships among factors that affect the relationship between buyer and supplier.

Step 1: Identifying a set of factors: In this step, the factors influencing buyer-supplier relationships must be recognized, which can be obtained from literature review, past research studies, and opinions of experts in the determined area, etc. (Table 1). Therefore, for determining the contextual relationship among factors influencing BSR, 72 experts from different manufacturing sectors in Tunisia are participated in this task. Most of the respondents held positions in Tunisian manufacturing related to purchasing activities (Table 2).

Table 2

Demographic profile of respondents (in \%)

\begin{tabular}{|c|c|c|c|c|c|c|}
\hline \multirow[t]{2}{*}{ Job title } & $\begin{array}{c}\text { Director } \\
\text { Purchasing }\end{array}$ & $\begin{array}{l}\text { Purchasing } \\
\text { Manager }\end{array}$ & $\begin{array}{l}\text { Senior } \\
\text { Buyer }\end{array}$ & $\begin{array}{c}\text { Purchasing } \\
\text { Assistant }\end{array}$ & $\begin{array}{l}\text { Manager } \\
\text { logistics }\end{array}$ & $\begin{array}{c}\text { Supply Chain } \\
\text { Manager }\end{array}$ \\
\hline & 11.11 & 25 & 13.88 & 30.55 & 12.5 & 6.94 \\
\hline \multirow[t]{2}{*}{$\begin{array}{l}\text { Educational } \\
\text { qualification }\end{array}$} & Diploma & $\begin{array}{c}\text { Bachelor's } \\
\text { degree }\end{array}$ & $\begin{array}{l}\text { Master's } \\
\text { degree }\end{array}$ & Doctoral & & \\
\hline & 19.44 & 58.33 & 22.22 & 0 & & \\
\hline \multirow[t]{2}{*}{$\begin{array}{l}\text { Experience } \\
\text { (in years) }\end{array}$} & $<5$ & 5 to 10 & 11 to 15 & $>15$ & & \\
\hline & 13.88 & 47.22 & 31.94 & 6.94 & & \\
\hline \multirow[t]{2}{*}{ Sector } & $\begin{array}{l}\text { Textile and } \\
\text { clothing }\end{array}$ & Plastics & Chemistry & $\begin{array}{c}\text { Agro } \\
\text { alimentary }\end{array}$ & $\begin{array}{l}\text { Leather \& } \\
\text { Shoes }\end{array}$ & \\
\hline & 22.22 & 12.5 & 20.83 & 38.88 & 5.55 & \\
\hline
\end{tabular}


Step 2: Building a structural self-interaction matrix (SSIM): The relation between the critical factors is presented in the SSIM by collecting the opinions of the experts. The relationship between factors $i$ and $j$ was defined by four symbols (Mathiyazhagan et al., 2013):

- V: Factor $i$ can affect in factor $j$

- A: Factor $j$ can lead or have influence to factor $i$

- X: Factors $i$ and $j$ help to attain or influence each other

- O: No relation between factors $i$ and $j$

The number of pairwise comparison used to build the SSIM are $((\mathrm{NV}) \times(\mathrm{NV}-1) / 2)$, wherever NV represents the number of variables. On the basis of the feedback obtained from experts by using above notations (VAXO), the SSIM for the eleven factors were developed (Table 3).

Table 3

Structural self-interaction matrix (SSIM)

\begin{tabular}{|c|c|c|c|c|c|c|c|c|c|c|c|c|c|}
\hline No. & & 1 & 2 & 3 & 4 & 5 & 6 & 7 & 8 & 9 & 10 & 11 & 12 \\
\hline 1 & Commitment & $X$ & $A$ & $\bar{A}$ & $O$ & $O$ & $O$ & $V$ & $\bar{A}$ & $O$ & $A$ & $A$ & $A$ \\
\hline 2 & Trust & & $X$ & $V$ & $A$ & $A$ & $A$ & V & $A$ & V & $A$ & V & $V$ \\
\hline 3 & Satisfaction & & & $X$ & $A$ & $A$ & $A$ & $V$ & $O$ & $A$ & $A$ & $X$ & $X$ \\
\hline 4 & Innovation and technology & & & & $X$ & $X$ & V & $O$ & $O$ & V & V & $O$ & $O$ \\
\hline 5 & Information exchange & & & & & $X$ & $V$ & $O$ & V & $O$ & $V$ & $O$ & $V$ \\
\hline 6 & Quality & & & & & & $X$ & $V$ & $V$ & $V$ & $X$ & $V$ & $V$ \\
\hline 7 & Production capabilities & & & & & & & $X$ & $A$ & $A$ & $A$ & $A$ & $A$ \\
\hline 8 & Safeguards & & & & & & & & $X$ & $X$ & $A$ & $O$ & $O$ \\
\hline 9 & Cost reduction & & & & & & & & & $X$ & $A$ & $V$ & $O$ \\
\hline 10 & Flexibility & & & & & & & & & & $X$ & $V$ & $V$ \\
\hline 11 & Cooperation & & & & & & & & & & & $X$ & $A$ \\
\hline 12 & Corporate reputation & & & & & & & & & & & & $X$ \\
\hline
\end{tabular}

Step 3: Building a reachability matrix: Substituting the four symbols (VAXO) by 1 and 0 as per the particular case, the obtained SSIM is then removed to a binary matrix. The substitution rule used in this study is presented in table 4. Specially, when the symbol of the relationship between two factors is $\mathrm{VAXO}$, the $(i, j)$ and $(j, i)$ of the initial reachability matrix $(I R M)$ are occupied in as the equivalent numbers in table 4. For example, if $(i, j)$ in the $\operatorname{SSIM}$ is $A$, then $(i, j)$ in the IRM is 0 , and $(j, i)$ is 1 . The $I R M$ for research factors was built following these rules.

\section{Table 4}

ISM Substitution rule

\begin{tabular}{lcc}
\hline SSIM & IRM & \\
\hline$(i, j)$ & $(i, j)$ & $(j, i)$ \\
$\mathrm{V}$ & 1 & 0 \\
$\mathrm{~A}$ & 0 & 1 \\
$\mathrm{X}$ & 1 & 1 \\
$\mathrm{O}$ & 0 & 0 \\
\hline
\end{tabular}

We used 'transitivity principle' to build the final reachability matrix $(F R M)$. The transitivity principle is based on the following: if variable $x$ is related to $y$ and $y$ is linked to $z$, then $x$ is necessarily related to $z$. In fact, any transitive connections between different variables should be explored (Sushil, 2017).

From the adjacent matrix (IRM), we can obtain the final reachability matrix (FRM) by applying the following Boolean algorithm: $0+0=1,0+1=1,1+0=1,1+1=1$ and $0 * 0=1,0+1=0,1 * 0=0,1 * 1=1 . F R M=$ $(I R M+I)^{n}, n>1$. Where: $I R M$ is the initial reachability matrix, $I$ is a n-order matrix with diagonal line entries of 1 and 0 for other entries. By using the Boolean algorithm, $F R M=(I R M+I)^{n}=I+$ $I R M+I R M^{2}+\cdots+I R M^{n}$ (shen et al.. 2006). The obtained FRM is presented in table 5. 
Table 5

Initial reachability matrix (IRM)

\begin{tabular}{cccccccccccccc}
\hline No. & $\mathbf{1}$ & $\mathbf{2}$ & $\mathbf{3}$ & $\mathbf{4}$ & $\mathbf{5}$ & $\mathbf{6}$ & $\mathbf{7}$ & $\mathbf{8}$ & $\mathbf{9}$ & $\mathbf{1 0}$ & $\mathbf{1 1}$ & $\mathbf{1 2}$ \\
\hline $\mathbf{1}$ & 1 & 0 & 0 & 0 & 0 & 0 & 1 & 0 & 0 & 0 & 0 & 0 \\
$\mathbf{2}$ & 1 & 1 & 1 & 0 & 0 & 0 & 1 & 0 & 1 & 0 & 1 & 1 \\
$\mathbf{3}$ & 1 & 0 & 1 & 0 & 0 & 0 & 1 & 0 & 0 & 0 & 1 & 1 \\
$\mathbf{4}$ & 0 & 1 & 1 & 1 & 1 & 1 & 0 & 0 & 1 & 1 & 0 & 0 \\
$\mathbf{5}$ & 0 & 1 & 1 & 1 & 1 & 1 & 0 & 1 & 0 & 1 & 0 & 1 \\
$\mathbf{6}$ & 0 & 1 & 1 & 0 & 0 & 1 & 1 & 1 & 1 & 1 & 1 & 1 \\
$\mathbf{7}$ & 0 & 0 & 0 & 0 & 0 & 0 & 1 & 0 & 0 & 0 & 0 & 0 \\
$\mathbf{8}$ & 1 & 1 & 0 & 0 & 0 & 0 & 1 & 1 & 1 & 0 & 0 & 0 \\
$\mathbf{9}$ & 0 & 0 & 1 & 0 & 0 & 0 & 1 & 1 & 1 & 0 & 1 & 0 \\
$\mathbf{1 0}$ & 1 & 1 & 1 & 0 & 0 & 1 & 1 & 1 & 1 & 1 & 1 & 1 \\
$\mathbf{1 1}$ & 1 & 0 & 1 & 0 & 0 & 0 & 1 & 0 & 0 & 0 & 1 & 0 \\
$\mathbf{1 2}$ & 1 & 0 & 1 & 0 & 0 & 0 & 1 & 0 & 0 & 0 & 1 & 1 \\
\hline
\end{tabular}

Table 6

Final reachability matrix (FRM)

\begin{tabular}{|c|c|c|c|c|c|c|c|c|c|c|c|c|}
\hline No. & 1 & 2 & 3 & 4 & 5 & 6 & 7 & 8 & 9 & 10 & 11 & 12 \\
\hline 1 & 1 & 0 & 0 & 0 & 0 & 0 & 1 & 0 & 0 & 0 & 0 & 0 \\
\hline 2 & 1 & 1 & 1 & 0 & 0 & 0 & 1 & $1^{*}$ & 1 & 0 & 1 & 1 \\
\hline 3 & 1 & 0 & 1 & 0 & 0 & 0 & 1 & 0 & 0 & 0 & 1 & 1 \\
\hline 4 & $1^{*}$ & 1 & 1 & 1 & 1 & 1 & $1^{*}$ & $1^{*}$ & 1 & 1 & $1 *$ & $1 *$ \\
\hline 5 & $1^{*}$ & 1 & 1 & 1 & 1 & 1 & $1 *$ & 1 & $1 *$ & 1 & $1 *$ & 1 \\
\hline 6 & $1 *$ & 1 & 1 & 0 & 0 & 1 & 1 & 1 & 1 & 1 & 1 & 1 \\
\hline 7 & 0 & 0 & 0 & 0 & 0 & 0 & 1 & 0 & 0 & 0 & 0 & 0 \\
\hline 8 & 1 & 1 & $1 *$ & 0 & 0 & 0 & 1 & 1 & 1 & 0 & $1 *$ & $1 *$ \\
\hline 9 & $1^{*}$ & $1 *$ & 1 & 0 & 0 & 0 & 1 & 1 & 1 & 0 & 1 & $1 *$ \\
\hline 10 & 1 & 1 & 1 & 0 & 0 & 1 & 1 & 1 & 1 & 1 & 1 & 1 \\
\hline 11 & 1 & 0 & 1 & 0 & 0 & 0 & 1 & 0 & 0 & 0 & 1 & $1 *$ \\
\hline 12 & 1 & 0 & 1 & 0 & 0 & 0 & 1 & 0 & 0 & 0 & 1 & 1 \\
\hline
\end{tabular}

Any entry $1 *$ shows how transitivity is integrated. For example, variable 4 (Innovation and technology) is connected to variable 3 (Satisfaction), and variable 3 to variable 7 (Production capabilities), then, variable 4 (Innovation and technology) is necessarily related to variable 7 (Production capabilities).

Step 4: Partitioning of reachability matrix: In this step, Buyer-supplier relationships factors are divided into different levels. By using the FRM, reachability set $(\mathrm{RS}(i))$ and antecedent set (AS $(i))$ are established. RS $(i)$ consists of the BSR factors themselves and other elements which may be affected or guided by it. $\mathrm{AS}(i)$, on the other hand, consists of the BSR factors themselves and other elements that can affect or push the variable under consideration. The intersection set (IS $(i))$ is obtained by the intersection between reachability and antecedent sets, $\operatorname{IS}(i)=\mathrm{RS}(i) \cap \mathrm{AS}(i)$. For a given factor $(i)$, if $\mathrm{RS}(i)=\mathrm{IS}(i)$, This element is then categorized into level I and given top ISM hierarchy place (Faisal, 2010). After completing the initial iteration (Table 6), the concerned factor was ordered in level I and discarded. The process is repeated to find the next level elements until the stage of each factor is reached (Govindan et al., 2012).

It can be observed from Table 7 that factor 7 has a same element in antecedent and intersection set, so this factor is classified in the first level. When the elements at the top level were recognized, they will be removed from the reachability set of other factors (Mathiyazhagan et al., 2013).

For the next iteration, this factor (7) has not been considered. Tables 8 to 12 depict the results of the following iterations in which factors are shown with levels. The identification of levels helps in making the digraph and the final model. The lower level power suggested these variables are at the top of the ISM diagram and for their own level would not relate to other overhead variables. Therefore, these variables can be affected by other variables. High level means these variables are put at the bottom of the hierarchy and that can influence the other variables of the BSR. 
Table 7

Level partition-iteration 1

\begin{tabular}{ccccc}
\hline $\boldsymbol{i}$ & $\mathbf{R S}(\boldsymbol{i})$ & $\mathbf{A S}(\boldsymbol{i})$ & $\mathbf{R S}(\boldsymbol{i}) \cap \mathbf{A S}(\boldsymbol{i})$ & level \\
\hline 1 & 17 & 12345689101112 & 1 & \\
2 & 1237891112 & 24568910 & 289 & \\
3 & 1371112 & 2345689101112 & 31112 & \\
4 & 123456789101112 & 45 & 45 & \\
5 & 123456789101112 & 45 & 610 & \\
6 & 1236789101112 & 45610 & 2 & \\
7 & 7 & 123456789101112 & 289 & \\
8 & 1237891112 & 24568910 & 289 & \\
9 & 1237891112 & 24568910 & 31112 & \\
10 & 1236789101112 & 45610 & 31112 & \\
11 & 1371112 & 2345689101112 & & \\
12 & 1371112 & 2345689101112 & \\
\hline
\end{tabular}

Table 8

Level partition-iteration 2

\begin{tabular}{ccccc}
\hline $\boldsymbol{i}$ & $\mathbf{R S}(\boldsymbol{i})$ & $\mathbf{A S}(\boldsymbol{i})$ & $\mathbf{R S}(\boldsymbol{i}) \cap \mathbf{A S}(\mathbf{i})$ & level \\
\hline 1 & 1 & 12345689101112 & 1 & II \\
2 & 123891112 & 24568910 & 289 & \\
3 & 131112 & 2345689101112 & 31112 & \\
4 & 12345689101112 & 45 & 45 & \\
5 & 12345689101112 & 45 & 610 & \\
6 & 123689101112 & 24568910 & 289 & \\
8 & 123891112 & 24568910 & 289 & \\
9 & 123891112 & 45610 & 310 & \\
10 & 123689101112 & 2345689101112 & 31112 & \\
11 & 131112 & 2345689101112 & & \\
12 & 131112 & & & \\
\hline
\end{tabular}

Table 9

Level partition-iteration 3

\begin{tabular}{|c|c|c|c|c|}
\hline$i$ & $\mathbf{R S}(i)$ & $\mathbf{A S}(i)$ & $\mathbf{R S}(i) \cap \mathbf{A S}(i)$ & leel \\
\hline 2 & 23891112 & 24568910 & 289 & \\
\hline 3 & 31112 & 2345689101112 & 31112 & III \\
\hline 4 & 2345689101112 & 45 & 45 & \\
\hline 5 & 2345689101112 & 45 & 45 & \\
\hline 6 & 23689101112 & 45610 & 610 & \\
\hline 8 & 23891112 & 24568910 & 289 & \\
\hline 9 & 23891112 & 24568910 & 289 & \\
\hline 10 & 23689101112 & 45610 & 610 & \\
\hline 11 & 31112 & 2345689101112 & 31112 & III \\
\hline 12 & 31112 & 2345689101112 & 31112 & III \\
\hline
\end{tabular}

\section{Table 10}

Level partition-iteration 4

\begin{tabular}{ccccc}
\hline $\mathbf{i}$ & $\mathbf{R S}(\boldsymbol{i})$ & $\mathbf{A S}(\boldsymbol{i})$ & $\mathbf{R S}(\boldsymbol{i}) \cap \mathbf{A S}(\boldsymbol{i})$ & level \\
\hline 2 & 289 & 24568910 & 289 & \\
4 & 24568910 & 45 & 45 & \\
5 & 24568910 & 45 & 45 & \\
6 & 268910 & 45610 & 610 & \\
8 & 289 & 24568910 & 289 & IV \\
9 & 289 & 24568910 & 289 & IV \\
10 & 268910 & 45610 & 610 & \\
\hline
\end{tabular}


Table 11

Level partition-iteration 5

\begin{tabular}{ccccc}
\hline $\boldsymbol{i}$ & $\mathbf{R S}(\boldsymbol{i})$ & $\mathbf{A S}(\boldsymbol{i})$ & $\mathbf{R S}(\boldsymbol{i}) \cap \mathbf{A S}(\boldsymbol{i})$ & level \\
\hline 4 & 45610 & 45 & 45 & \\
5 & 45610 & 45 & 45 & \\
6 & 610 & 45610 & 610 & $\mathrm{~V}$ \\
10 & 610 & 45610 & 610 & $\mathrm{~V}$ \\
\hline
\end{tabular}

Table 12

Level partition-iteration 6

\begin{tabular}{ccccc}
\hline $\boldsymbol{i}$ & $\mathbf{R S}(\boldsymbol{i})$ & $\mathbf{A S}(\boldsymbol{i})$ & $\mathbf{R S}(\boldsymbol{i}) \cap \mathbf{A S}(\boldsymbol{i})$ & level \\
\hline 4 & 45 & 45 & 45 & VI \\
5 & 45 & 45 & 45 & VI \\
\hline
\end{tabular}

Step 5: Establishing the ISM Model: The ISM model for the BSR was established with the help of level according the factors classification presented in Tables 6 to 12. The canonical matrix is used for generating the digraph. It is initially created with transitivity, thus obtaining the final diagram by eliminating the indirect ties. Eventually, as shown in Fig. 1, this digraph is transformed through an ISM model. This step established the collaborative relationships between factors in order to illustrate the influence chain in the system.

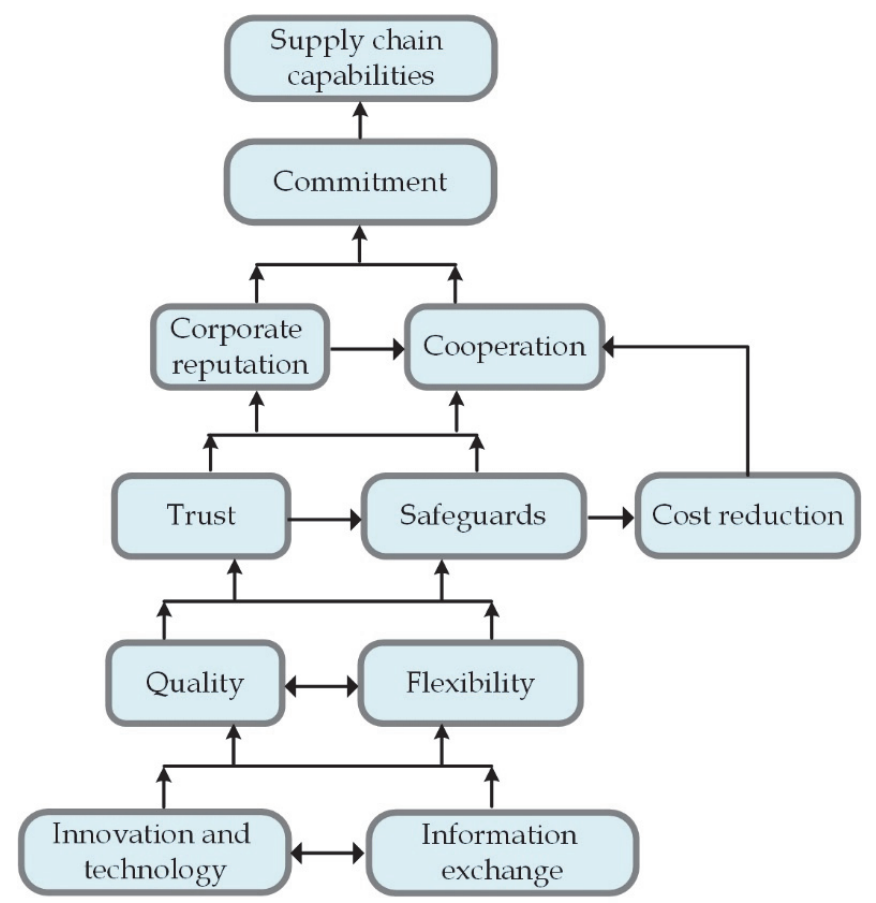

Fig.1. ISM model of buyer-supplier relationships

\subsection{Cross-impact matrix multiplication applied to classification}

The hierarchy classification presented in Fig. 1 can be further inspected by exploring their driving power $(D R P)$ and dependence power $(D N P)$. DRP of any factor is obtained by adding all the entries in the respective $F R M$ row. while, $D N P$ of one element is obtained by the addition of all entries in the respective FRM column. DRP and DNP for all factors are presented in Table 13. As a result, Information exchange (5) has $D N P$ value of twelve and $D N P$ value of two. This entails that 5 impacts twelve factors and it is influenced by two factors.

As an outcome of these results, each BSR variable can be placed in a two-dimensional graph, as shown in Fig.2. According to this classification, first group comes from autonomous variables that possess a 
weak DRP and DNP. These factors have a few links and are relatively detached from the system (Muruganantham et al., 2018). As shown in Fig.2, there are two autonomous factors: quality (6) and flexibility (10).

The second group includes dependent variables with weak $D R P$ and strong $D N P$. These variables are generally considered as output of the system and they are reached through the help of many other factors of the system. According to their high dependency, these factors are positioned at the top of the hierarchy. In this case, the dependent factors group comprises two factors: Innovation and technology (5) and Information exchange (6).

The third group is composed of linkage variables. Such variables are important both for driving and for dependence. The linkage factors are characterized by the instability, because any intervention on those variables will affect the other variables and impact input on itself (Yadav \& Barve, 2015). These variables are generally placed at the intermediate level of the ISM hierarchy. In this case, there are five factors in this category: Trust (2), Supply chain capabilities (7), Safeguards (8), Cost reduction (9) and Corporate reputation (12).

The fourth group is formed by independent variables with a strong $D R P$ and weak $D N P$. In the present study, this cluster includes three factors: Commitment (1) Satisfaction (3) and Cooperation (11).

\section{Table 13}

Driving-power and dependence-power table

\begin{tabular}{ccccccccccccc}
\hline $\boldsymbol{i}$ & 1 & 2 & 3 & 4 & 5 & 6 & 7 & 8 & 9 & 10 & 11 & 12 \\
\hline $\boldsymbol{D R P}$ & 2 & 8 & 5 & 12 & 12 & 1 & 8 & 8 & 10 & 5 & 5 & 12 \\
$\boldsymbol{D N P}$ & 11 & 7 & 10 & 2 & 2 & 4 & 12 & 7 & 7 & 4 & 10 & 10 \\
\hline DRP: Driving Power, DNP: Dependence Power & & &
\end{tabular}

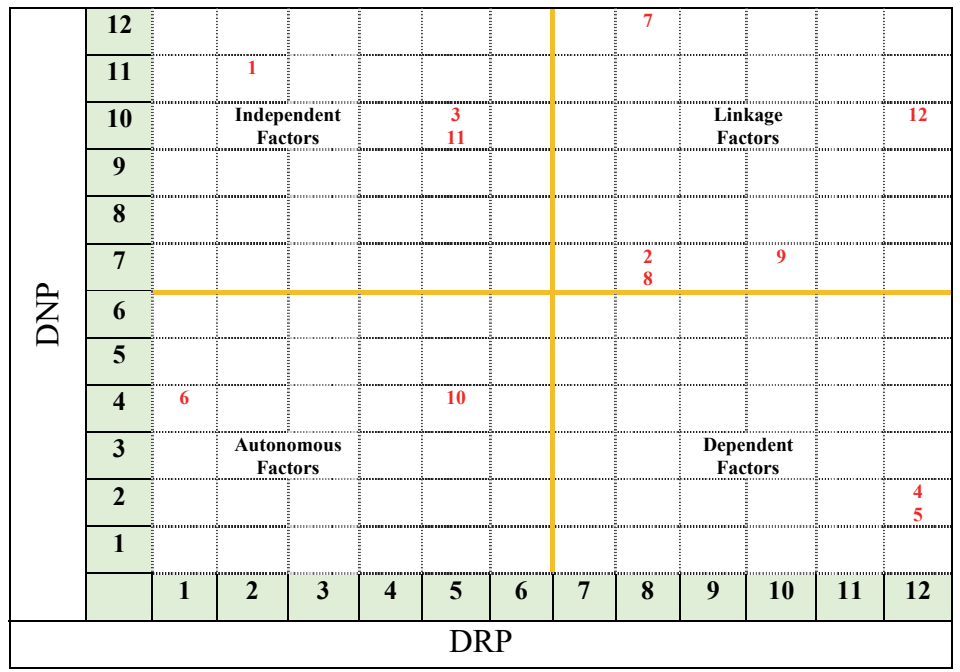

Fig. 2. DRP and DNP diagram

\section{Discussion on findings}

The present study has aimed to identify the critical success factors, create contextual relationships between factors and make the hierarchy model representing the relationship between factors affecting BSR. Six levels were created in the hierarchy structure, starting with factors that have high driving force at the bottom and high dependency power at the top of the model. Factors classified in the lower level of hierarchy affects factors at the upper levels. Innovation and technology (5) and Information exchange (6), which are a technology related factors, are the most basic factors, which drive the BSR. In fact, a priority measures and actions should be considered for these factors. This is in line with previous studies (Hvolby \& Trienekens, 2002; Wamba et al., 2015), suggesting that the use of information and communication technology is considered as an elementary facilitator in the development and coordination of relationship between buyer and seller. 
In the moderately significant category of CSFs, three levels (level 2 to level 5) were identified. These three levels are impacted by the lower level factors and have the capability to influence the factors in the upper levels. As it can be seemed from fig. 1, quality (6) and flexibility (10) were involved in three influence chains including the quality (6) and flexibility (10) leading the trust (2) and safeguards (8), and then, the cooperation (11) and corporate reputation (12), and then, the commitment (1). All these factors finally lead to the supply chain capabilities (7). SC capability refers to the process of coordination and cooperation between suppliers, producers and consumers in order to achieve common objectives. On the other hand, supply chain capability, reflects the robustness and agility of supply chain on disruptions.

\section{Conclusions and future research directions}

This study has developed a conceptual framework as a hierarchy of critical factors affecting BSR. Twelve key factors are identified in this research, by means of ISM analysis, theses twelve factors are hierarchically organized and divided into six groups. Next, the driving and dependency power is applied to separate factors into four clusters: two autonomous factors, two dependent factors, five linkage factors and three independent factors, as presented in Fig. 1.

It can be perceived that none of the previous studies of BSR have employed a structural modelling approach to hierarchizing and classifying factors. Previous study typically defined only factors that affect buyer-supplier relationships. Against, this research is the exclusive study to exploring the mutual influences amongst BSR factors. As a result of this work, it can be suggested that buyer and supplier should be given special care to overcome the key factors like innovation and technology and information exchange. In addition, the developed hierarchy highlights the significance of linkage factors in BSR like trust, safeguards and commitment which are considered as critical elements to sustain relationships between buyer and supplier.

Inputs collected from experts using the ISM methodology are deemed subjective in nature. If expert's inputs are biased, then the final result can be affected. In addition, there are some limitations in the application of ISM approach and future research can address some of their issues. First, ISM provides interrelationships among various factors without identifying the relative influence of each factor. However, the model was not tested statistically. This can be solved by using of Structural Equation Modeling (SEM). Second, this study takes into account all the possible factors having a direct or indirect impact on SBR. To improve accuracy and reliability of the model, it is imperative to apply the Multi-criteria decision-making (MCDM) such as Analytic hierarchy process (AHP), Fuzzy AHP, Analytic network process (ANP). By using these tools, it is possible to assign weights to the critical factors identified in this study.

\section{References}

Abuzeinab, A., Arif, M., \& Qadri, M.A. (2017). Barriers to MNEs green business models in the UK construction sector: An ISM analysis. Journal of Cleaner Production, 160, 27-37.

Akgün, A.E., Byrne, J., Keskin, H., Lynn, G.S., \& Imamoglu, S.Z. (2005). Knowledge networks in new product development projects: a transactive memory perspective. Information \& Management, 42(8), 1105-1120.

Amy, H.I.L. (2009). A fuzzy AHP evaluation model for buyer-supplier relationships with the consideration of benefits, opportunities, costs and risks. International Journal of Production Research, 47(15), 4255-4280.

Arráiz, I., Henríquez, F. \& Stucchi, R. (2013). Supplier development programs and firm performance: evidence from Chile. Small Business Economics, 41(1), 277-293.

Bhaskar, B.G., Rakesh, D.R., \& Narkhede, B. (2019). Determinants of sustainable supply chain management: A case study from the oil and gas supply chain. Sustainable Production and Consumption, 17, 241-253.

Brito, L.A.L., Brito, E.P. \& Hashiba, L.H. (2014). What type of cooperation with suppliers and customers leads to superior performance? Journal of Business Research, 67, 952-959. 
Caglio, A., \& Ditillo, A. (2012). A Opening the black box of management accounting information exchanges in buyer-supplier relationships. Management Accounting Research, 23(2), 61-78.

Cannon, J.P. \& Homburg, C. (2001). Buyer-supplier relationships and customer firm costs. Journal of Marketing, 65(1), 29-43.

Carmen, S.B.M. \& Cubillo, G. (2019). Supplier behavior and its impact on customer satisfaction: A new characterization of negotiation behavior. Journal of Purchasing and Supply Management, 25(1), 53-68.

Chae, S., Choi, T.Y. \& Hur, D. (2017). Buyer power and supplier relationship commitment: A cognitive evaluation theory perspective. Journal of Supply Chain Management, 53, 39-60.

Chiu, W., Kwag, M.S. \& Bae, J.S. (2015). Customers as partial employees: The influences of satisfaction and commitment on customer citizenship behavior in fitness centers. Journal of Physical Education and Sport, 15(4), 627-633.

Christy, D.P. \& Grout, J.R. (1994). Safeguarding supply chain relationships. International Journal of Production Economics, 36(3), 233-242.

Clampit, J., Kedia, B., Fabian, F. \& Gaffney, N. (2015). Offshoring satisfaction: The role of partnership credibility and cultural complementarity. Journal of World Business, 50, 79-93.

Cox, A. (2004). Business relationship alignment: on the commensurability of value capture and mutuality in buyer and supplier exchange. Supply Chain Management, 9(5), 410-420.

De Toni, A., \& Tonchia, S. (2005). Definitions and linkages between operational and strategic flexibilities. Omega, 33(6), 525-540.

Doney, P.M. \& Cannon, J.P. (1997). An examination of the nature of trust in buyer-seller relationships. Journal of Marketing, 61(2), 35-51.

Faisal, M.N. (2010). Analysing the barriers to corporate social responsibility in supply chains: an interpretive structural modelling approach. International Journal of Logistics Research and Applications, 13(3), 179-95.

Fombrun, C.J., \& Pan, M. (2006). Corporate reputations in China: How do consumers feel about companies? Corporate Reputation Review, 9(3), 165 - 170.

Govindan, K., Palaniappan, M., Zhu, Q., \& Kannan, D. (2012). Analysis of third party reverse logistics provider using interpretive structural modeling. International Journal of Production Economics, 140(1), 204-211.

Han, S.L., Sung, H.S. \& Shim, H.S. (2014). Antecedents and performance outcomes of flexibility in industrial customer-supplier relationships. Journal of Business Research, 67(10), 2115-2122.

Huang, G.Q., Mak, K.L. \& Humphreys, P.K. (2003). A new model of the customer-supplier partnership in new product development. Journal of Materials Processing Technology 138, 3015.

Hüttinger, L., Schiele, H., \& Veldman, J. (2012). The drivers of customer attractiveness, supplier satisfaction and preferred customer status: A literature review. Industrial Marketing Management, 41(8), 1194-1205.

Hvolby, H.H. \& Trienekens, J. (2002). Supply Chain Planning Opportunities for Small and Medium Sized Companies. Computers in Industry, 49(1), 3-8.

Hwang, S., Kim, H., Hur, D., \& Schoenherr, T. (2019). Interorganizational information processing and the contingency effects of buyer-incurred uncertainty in a supplier's component development project. International Journal of Production Economics, 210, 169-183.

Islam, A.S.M.T. (2019). End of the day, who is benefited by Lean Manufacturing? A dilemma of communication and pricing in buyer-supplier relationship. Manufacturing Letters, 21, 17-19.

Kingshott, R.P.J. (2006). The impact of psychological contracts upon trust and commitment within supplier-buyer relationships: A social exchange view. Industrial Marketing Management, 35(6), 724-739.

Krause, D.R., Handfield, R.B. \& Tyler, B.B. (2007). The relationships between supplier development, commitment, social capital accumulation and performance improvement. Journal of Operations Management, 25(2), 528-545. 
Kumar, D. \& Rahman, Z. (2016). Buyer supplier relationship and supply chain sustainability: empirical study of Indian automobile industry. Journal of Cleaner Production, 131, 836-848.

Liu, Y., Li, Y., Shi, L.H., \& Liu, T. (2017). Knowledge transfer in buyer-supplier relationships: The role of transactional and relational governance mechanisms. Journal of Business Research, 78, 285-293.

Luo, Y., Liu, Y., Yang, Q., Maksimov, V., \& Hou J. (2015). Improving performance and reducing cost in buyer-supplier relationships: The role of justice in curtailing opportunism. Journal of Business Research, 68(3), 607-615.

Luthra, S., Kumar, V., Kumar, S., \& Haleem, A. (2011). Barriers to implement green supply chain management in automobile industry using interpretive structural modeling technique: An Indian perspective. Journal of Industrial Engineering and Management, 4(2), 231-257.

Majumdar, A. \& Sinha, S.K. (2019). Analyzing the barriers of green textile supply chain management in Southeast Asia using interpretive structural modeling. Sustainable Production and Consumption 17, 176-187.

Manello, A., \& Calabrese, G. (2019). The influence of reputation on supplier selection: An empirical study of the European automotive industry. Journal of Purchasing and Supply Management, 25(1), 69-77.

Mathiyazhagan, K., Govindan, K., NoorulHaq, A., \& Geng Y. (2013). An ISM approach for the barrier analysis in implementing green supply chain management. Journal of Cleaner Production, 47, 283-297.

Matuleviciene, M., \& Stravinskiene, J. (2015). Identifying the Factors of Stakeholder Trust: A Theoretical Study, Procedia - Social and Behavioral Sciences, 213, 599-604.

Mesquita, L. \& Brush, T. (2008). Untangling safeguard and production coordination effects in longterm buyer-supplier relationships. Academy of Management Journal, 51, 785-807.

Mohanty, M.K. \& Gahan, D.P. (2002). Buyer Supplier Relationship in Manufacturing Industry Findings from Indian Manufacturing Sector. Business Intelligence Journal, 5(2), 319-333.

Money, K., Saraeva, A., Garnelo-Gomez, I., Pain, S., \& Hillenbrand, C. (2017). Corporate Reputation Past and Future: A Review and Integration of Existing Literature and a Framework for Future Research. Corporate Reputation Review, 20(3-4), 193-211.

Moon, K.K.L., Yi, C.Y., \& Ngai, E.W.T. (2012). An instrument for measuring supply chain flexibility for the textile and clothing companies. European Journal of Operational Research, 222(2), 191203.

Morgan, R.M. \& Hunt, S.D. (1994). The Commitment-Trust Theory of Relationship Marketing. Journal of Marketing, 58(3), 20-38.

Morrissey, W.J., \& Pittaway, L. (2006). Buyer-Supplier Relationships in Small Firms: The Use of Social Factors to Manage Relationships. International Small Business Journal, 24(3), 272-298.

Muruganantham, G., Vinodh, S., Arun, C.S., \& Ramesh, K., (2018). Application of interpretive structural modelling for analysing barriers to total quality management practices implementation in the automotive sector. Total Quality Management \& Business Excellence, 29 (5-6), 524-545.

Nyaga, G.N., Whipple, J.M., \& Lynch, D.F. (2010). Examining supply chain relationships: Do buyer and supplier perspectives on collaborative relationships differ?. Journal of Operations Management, 28, 101-114.

Parsons, A. (2002). What Determines Buyer-Seller Relationship Quality? An Investigation From the Buyer's Perspective. Journal of Supply Chain Management, 38, 4 - 12.

Paulraj, A., \& Chen IJ (2007). Strategic Buyer-Supplier Relationships, Information Technology and External Logistics Integration. Journal of Supply Chain Management, 43, 2-14.

Powers, T.L., \& Reagan, W.R. (2007). Factors influencing successful buyer-seller relationships. Journal of Business Research, 60(12), 1234-1242.

Ranaweera, C. \& Prabhu, J. (2003). The influence of satisfaction, trust and switching barriers on customer retention in a continuous purchasing setting. International Journal of Service Industry Management, 14(4), 374-395. 
Revilla, E. \& Villena, V.H. (2012). Knowledge integration taxonomy in buyer-supplier relationships: Trade-offs between efficiency and innovation. International Journal of Production Economics, 140(2), 854-864.

Roy, S., Sivakumar, K. \& Wilkinson, I.F. (2004). Innovation generation in supply chain relationships: A conceptual model and research propositions. Journal of the Academy of Marketing Science, 32, 61-79.

Sage, A. (1977). Interpretive Structural Modeling: Methodology for Large scale Systems. New York: McGraw-Hill.

Schönberger, L. (2011). Buyer-Supplier Relationships in Service Procurement - The Impact of Relationship Quality on Service Performance. In: Bogaschewsky R., Eßig M., Lasch R., Stölzle W. (eds). Supply Management Research. Gabler

Shen, L., Song, X., Wu, Y., Liao, S., Zhang, X. (2016). Interpretive structural modeling based factor analysis on the implementation of emission trading system in the Chinese building sector. Journal of Cleaner Production, 127, 214-227.

Suh, T. \& Houston, M.B. (2010). Distinguishing supplier reputation from trust in buyer-supplier relationships. Industrial Marketing Management, 39(5), 744-751.

Sushil (2017). Modified ISM/TISM process with simultaneous transitivity checks for reducing direct pair Comparisons. Global Journal of Flexible Systems Management, 18(4), 331-351.

Vargas, J.R.C., Mantilla, C.E.M. \& Jabbour, A.B.L.S. (2018). Enablers of sustainable supply chain management and its effect on competitive advantage in the Colombian context. Resources Conservation and Recycling, 139, 237-250.

Wagner, B.A., Murphy, M.D., \& Haughey, E. (1998). Evolution of partnering relationships: a supply chain perspective. In: Bititci U.S., Carrie A.S. (eds). Strategic Management of the Manufacturing Value Chain. IFIP - The International Federation for Information Processing, vol 2. Springer, Boston, MA.

Wamba, S. F., Akter, S., Edwards, A., Chopin, G., \& Gnanzou, D. (2015). How 'big data' can make big impact: Findings from a systematic review and a longitudinal case study. International Journal of Production Economics, 165, 234-246.

Warfield, J.W. (1974). Developing interconnected matrices in Structural modeling. IEEE Transcript on Systems, Men and Cybernetics, 4(1), 51-81.

$\mathrm{Wu}, \mathrm{J} ., \mathrm{Wu}, \mathrm{Z}$. \& Si, S. (2016). The influences of Internet-based collaboration and intimate interactions in buyer-supplier relationship on product innovation. Journal of Business Research, 69 (9), 3780-3787.

Yadav, D.K., \& Barve, A. (2015). Analysis of critical success factors of humanitarian supply chain: An application of Interpretive Structural Modeling. International Journal of Disaster Risk Reduction, 12, 213-225.

Yen, Y.X., Wang, S.T.E., \& Horng, D. J. (2011). Suppliers' willingness of customization, effective communication, and trust: a study of switching cost antecedents. Journal of Business \& Industrial Marketing, 26(4), 250-259.

Yu, W., Jacobs, M.A., Salisbury, W.D., \& Enns, H. (2013). The effects of supply chain integration on customer satisfaction and financial performance: An organizational learning perspective. International Journal of Production Economics, 146(1), 346-358.

Zhang, X., Duan, K., Zhao, H., Zhao, Y., Wang, X., \& Ordonez de Pablos, P. (2019). Can cooperation drive the success of suppliers in B2B crowdsourcing innovation projects? A large scale data perspective. Industrial Marketing Management.

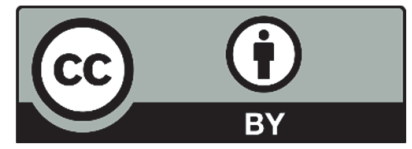

(C) 2020 by the authors; licensee Growing Science, Canada. This is an open access article distributed under the terms and conditions of the Creative Commons Attribution (CC-BY) license (http://creativecommons.org/licenses/by/4.0/). 